\section{Can the CureTime of Endodontic Sealers Affect Bond Strength to Root Dentin?}

Gabriela Campos Mesquita ${ }^{1}$, Crisnicaw Veríssimo², Luís Henrique Araújo Raposo ${ }^{1}$, Paulo César Freitas Santos-Filho ${ }^{2}$, Adérito Soares da Mota ${ }^{1}$, Carlos José Soares ${ }^{2}$

\author{
'Department of Occlusion, Fixed \\ Prosthodontics and Dental \\ Materials, School of Dentistry, \\ UFU - Federal University of \\ Uberlândia, Uberlândia, MG, Brazil \\ ${ }^{2}$ Department of Operative Dentistry \\ and Dental Materials, School of \\ Dentistry, UFU - Federal University of \\ Uberlândia, Uberlândia, MG, Brazil
}

Correspondence: Prof. Dr. Carlos José Soares, Avenida Pará, 1720, Bloco 4LA, Sala 42, Campus Umuarama, 38400-902 Uberlândia, MG, Brasil. Tel: +55-34-3218-2255. e-mail: carlosjsoares@umuarama.ufu.br

\section{Introduction}

The use of fiber posts luted with resin cements has been reported in several studies (1-3). Glass fiber posts have been widely used in restorative dentistry because of their elastic modulus similar to dentin and their capability to distribute stress more effectively than cast post-and-cores (4). However, fiber post luting is a very critical procedure, which may be affected by several issues, such as dentin contamination, post surface treatment, shrinkage stress and polymerization limitation $(5,6)$.

The post luting procedure can be performed in the same session of the endodontic therapy (7). However, it is supposed that the unset endodontic sealer can contaminate dentin, interfering on bonding to the root canal walls (8, 9), therefore contraindicating post luting immediately after endodontic filling (10). Phenolic eugenol-based compounds and residues of calcium hydroxide sealers can negatively influence the bond strength between fiber posts and root dentin when adhesive luting is performed immediately after endodontic treatment $(7,9)$. This supposedly occurs due to the incomplete cure reaction of these sealers, which affects the adhesion of resin cements, reducing their bond strength to tooth tissues (7).

Conventional dual-cure resin cements are claimed to produce higher bond strength values when associated to fiber posts (11). On the other hand, self-adhesive resin cements produce similar or even higher bond strength values than conventional resin cements when used for fiber post luting $(12,13)$. Amongst the available methods to evaluate the bond strength of fiber posts to root canal dentin, the push-out test seems the most suitable option (14). The stress distribution in the push-out specimens has shown to be more homogeneous than in microtensile specimens (15). Additionally, data variability is more acceptable and the bond strength of different root depths can be adequately accessed by this method (15-17).

This way, the hypothesis tested in this study was that the push-out bond strength of fiber posts to the root dentin would not be influenced either by the period elapsed between root canal filling and post luting or by the type of the resin cement.

\section{Material and Methods}

Forty bovine incisors were selected and stored in $0.1 \%$ buffered thymol solution (Biopharma, Uberlândia, MG, Brazil). The selection criterion considered the similarity between the external and internal morphology of the teeth and a canal diameter smaller than $1 \mathrm{~mm}$ at the cervical limit. Roots $15 \mathrm{~mm}$ long, were produced after removing the coronal portion of the teeth. The canals were instrumented $1 \mathrm{~mm}$ from the apex using the stepback technique, with \#25 and \#30 K-Files and number 2, 3 and 4 Gates-Glidden burs (Dentsply Maillefer, Ballaigues, Switzerland), with 0.7, 0.9 and $1.1 \mathrm{~mm}$ in diameter, respectively. The prepared canals had an approximate diameter of $1.5 \mathrm{~mm}$ in the cervical third and $0.9 \mathrm{~mm}$ in the middle and apical thirds. Root canals were irrigated with $1 \%$ sodium hypochlorite 
(Biodinâmica, Londrina, PR, Brazil). After final irrigation with distilled water, canals were dried with absorbent papers, filled with gutta-percha (Dentsply-Maillefer) and calcium-hydroxide based endodontic sealer (Sealer 26; Dentsply, Petrópolis, RJ, Brazil).

Roots were divided into 2 groups according to the time elapsed between endodontic filling and post luting $(n=20)$ : Immediately - glass fiber post luting immediately after endodontic filling; and Delayed - post luting performed 7 days after endodontic filling. The roots were also subdivided according to the resin cement used for post luting: RXARC (RelyX ARC, A3 shade, 3M ESPE, St. Paul, MN, USA) and RXUNC (RelyX Unicem, A3 shade, 3M ESPE). Cylindrical-tapered glass fiber posts were used, with 1.25 and $2.0 \mathrm{~mm}$ apical and cervical diameters, respectively (Whitepost DC no.3; FGM, Joinville, SC, Brazil). Posts were cleaned with 70\% alcohol solution and a silane coupling agent was applied and left to react for $1 \mathrm{~min}$ (Prosil, FGM). For RXARC specimens, the canal was etched with $37 \%$ phosphoric acid for $15 \mathrm{~s}$, rinsed with water and dried with absorbent papers. A 2-step etch-and-rinse adhesive system (Single Bond Plus, 3M ESPE) was applied to the root canal walls and polymerized for $20 \mathrm{~s}$ with a LED-curing unit (RadiiCal; SDI, Victoria, Australia). The resin cement was manipulated according to the manufacturer's instructions and applied to the post and to the root canals with a \#35 $\mathrm{K}$ file. All posts were gently inserted and held in position with pressure for 3 min. Excess cement was removed after the first minute and light-curing was performed for $40 \mathrm{~s}$ on incisal, buccal and lingual surfaces, totaling $120 \mathrm{~s}$. For the RXUNC specimens, the root canals walls were only cleaned with $0.9 \%$ saline solution and dried with absorbent papers. The resin cement was manipulated according to

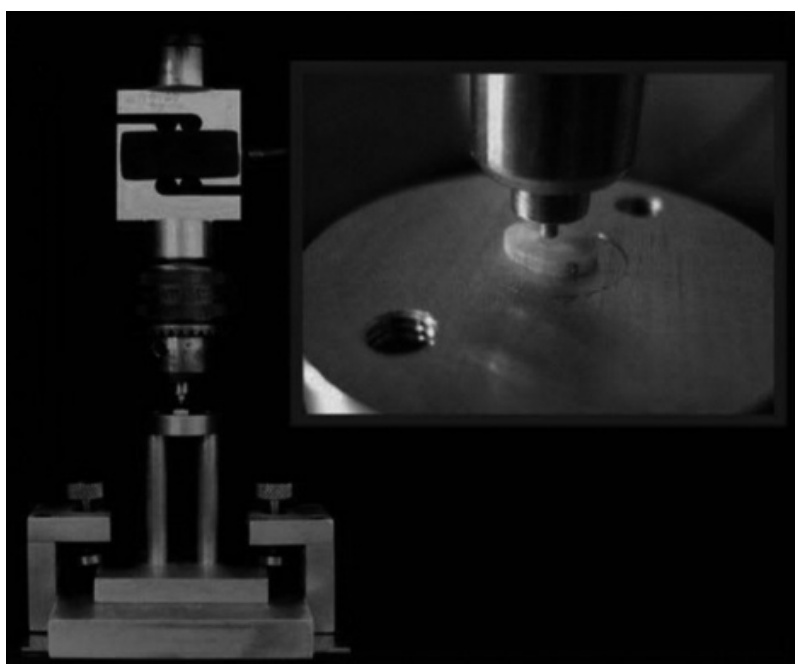

Figure 1. Root/post slice in the mechanical testing machine for the push-out test. the manufacturer's instructions and post insertion was carried-out as described previously.

Roots were sectioned perpendicular to their long axis with a slow-speed diamond saw (Isomet 1000; Buehler, Lake Bluff, IL, USA) resulting in two slices $1.0 \mathrm{~mm}$ thick for each root depth (cervical, middle and apical). The slices were analyzed using optical microscopy at 40x magnification (Mitutoyo, Kanagawa, Japan) to measure both major and minor post diameters in millimeters and to identify any cracks or failures. Then, the slices were positioned allowing the $1.0 \mathrm{~mm}$ diameter load applicator tip to coincide with the center of the post and with the $3.0 \mathrm{~mm}$ diameter orifice of the metal base (Fig. 1) (7).

Specimens were loaded in a mechanical testing machine (DL 2000; EMIC, São José dos Pinhais, PR, Brazil) at a crosshead speed of $0.5 \mathrm{~mm} / \mathrm{min}$. Bond strength was calculated (MPa) dividing the load at failure (N) by the area of the bonded interface $\left(\mathrm{mm}^{2}\right)$. The area of the bonded interface was calculated as follows:

\section{$A=\pi^{*} h^{*}(D+d) / 2$}

where $A$ is the area of the bonded interface, $\pi$ is 3.14 , $h$ is the thickness of the post segment $(\mathrm{mm}), D$ is the major diameter, and $d$ is the minor diameter of the post segment (mm).

Data were statistically analyzed using two-way ANOVA and Tukey's test $(\alpha=0.05)$ in a split plot arrangement, with plots represented by the moment of post luting, luting resin cement and root depths.

\section{Results}

Mean bond strength values and standard deviations for the experimental groups according to the moment of post luting and root depths are presented in Table 1 and illustrated in Figure 2.

Two-way ANOVA indicated significant differences for the bond strength values among the groups $(p<0.05)$. The isolated factors, moment of post luting, luting resin cement, root depths and also the interaction among factors were significant $(p<0.01)$. In general, it was shown that both luting resin cements presented increased bond strengths when post cementation was performed 7 days after the endodontic filling. Different bond strengths were verified at the three root depths for the conventional resin cement when posts were luted after 7 days. However, this behavior was not verified for the self-adhesive resin cement at the same period. In general, bond strength values were higher for the posts luted with the self-adhesive resin cement compared with those luted with the conventional resin cement.

\section{Discussion}

The hypothesis of this study was rejected since the 

influenced by the time elapsed between the endodontic filling and the post luting. The results showed that bond strength values for both luting resin cements tested were higher when the fiber posts were luted 7 days after the endodontic treatment. These results agree with those of previous studies, which indicated that contamination of the post space is minimized when the endodontic sealer is allowed to set completely before post luting $(7,9)$. Additionally, it is postulated that the adhesive procedures are favored when the dentin is free of previous contamination from eugenol-based endodontic sealers $(7,9)$. This behavior is observed not only for eugenol-based sealers, but also to epoxy-resin and calcium hydroxidebased sealers, as used in this study $(8,10,18)$. Moreover, the preparation of the post space after the setting period of the sealer reduces the possibility of apical infiltration due to improved apical sealing (19). bond strength between the root dentin and fiber posts was

The unset endodontic sealer had an influence on the adhesion of the luting resin cements to root canal dentin since the bond strength values were lower when the post space preparation and luting procedure were performed immediately after endodontic filling (Fig. 2). This fact may be due to the contamination of the root canal dentin by the unset sealer, which is transported from the apical region to the whole canal length by the paper points used to dry the canals or by the disposable applicators used to apply the adhesive system to the root walls (9).

As regards the resin cements used in this study, the bond strength values of RelyX Unicem were higher than those obtained by RelyX ARC after 7 days of endodontic treatment. Compared with conventional resin cements, selfadhesive cements, such as RelyX Unicem, have presented higher bond strength to root dentin $(20,21)$. Furthermore, these cements allow a less sensitive application technique, are easier to handle and produce reliable bond strength (11). The self-adhesive resin cement evaluated was not influenced by the different root depths as the conventional resin cement when delayed (22). This may be due to the fact that in the apical portion the number and configuration of dentin tubules are less dense (23) and dentin is more sclerotic (24). Thus, the formation of resin tags is reduced. On the other hand, this apical calcification increases the availability of apatite crystals, which is the ideal substrate for self-adhesive resin cements. Additionally, the polymerization initiator of the selfadhesive resin cement is not an alkaline amine, which can be deactivated by the acidic environment, as may occur for the conventional resin cements (25).

Based on the results of this study, clinicians should be careful in performing

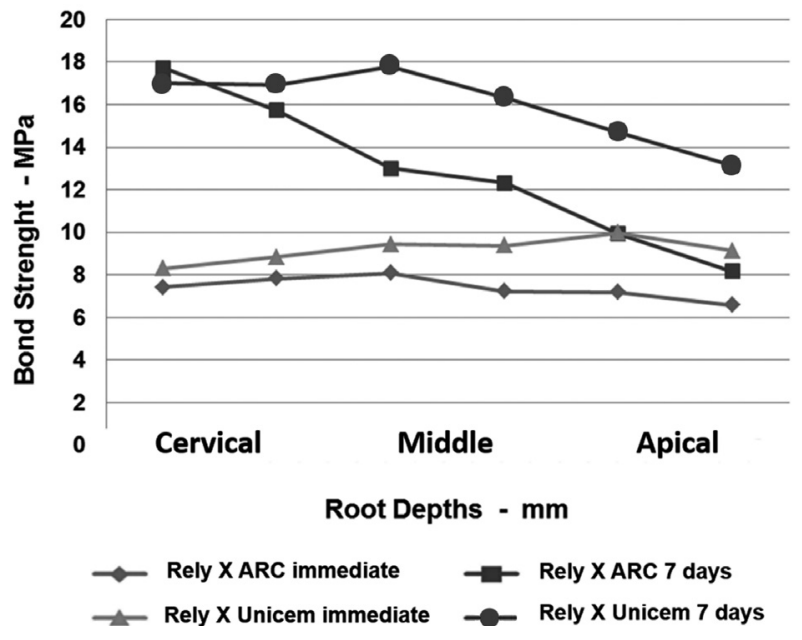

Figure 2. Bond strength of resin cements according to the moment of post luting and root depths. immediate cementation of fiber posts after endodontic filling when calcium-hydroxide based endodontic sealer is used, as post luting after 7 days of root filling resulted in higher bond strength values for both resin cements. Moreover, the self-adhesive resin cement showed higher bond strength values compared with the conventional resin cement, being less affected by the different root dentin depths. Then, this material should be preferred for luting procedures involving fiber posts.

\section{Resumo}

0 tempo de presa de cimentos endodônticos pode afetar a resistência de união de pinos de fibra de vidro à dentina radicular. Quarenta dentes foram selecionados e tratados endodonticamente com cimento à base de hidróxido de cálcio. Em seguida, os mesmos foram divididos em dois grupos de acordo com o tempo decorrido entre o tratamento 
endodôntico e a cimentação definitiva ( $n=20)$ : Imediato - pinos de fibra de vidro cimentados após o tratamento endodôntico; e Mediato cimentação do pino realizada 7 dias após o tratamento endodôntico. As raizes foram subdivididas de acordo com o cimento resinoso (RelyX ARC e RelyX Unicem). As amostras foram armazenadas a $37^{\circ} \mathrm{C}$ durante 24 $\mathrm{h}$ e seccionadas em seis fatias de $1 \mathrm{~mm}$ de espessura relacionadas com terços cervical, médio e apical. Os espécimes foram submetidos a teste de push-out a uma velocidade de 0,5 mm/min e os valores de resistência de união obtidos (MPa) foram submetidos à análise de variância em esquema de parcelas subdivididas e teste de Tukey $(\alpha=0,05)$. Para os cimentos RelyX ARC e Unicem, a resistência de união foi maior quando os pinos foram cimentados 7 dias após o tratamento endodôntico. RelyX Unicem apresentou valores de resistência de união superiores ao RelyX ARC para os periodos de cimentação. Concluiu-se que a cimentação do pino de fibra de vidro deve ser feita após o completo tempo de presa do cimento endodôntico. Cimentos resinosos auto-adesivos devem ser preferidos para cimentação de pinos de fibra.

\section{Acknowledgments}

This study was supported by grants from FAPEMIG and CNPq.

\section{References}

1. Plotino G, Grande NM, Bedini R, Pameijer CH, Somma F. Flexural properties of endodontic posts and human root dentin. Dent Mater 2007;23:1129-1135.

2. Soares $C J$, Valdivia $A D$, da Silva GR, Santana $F R$, Menezes $M$ de $S$. Longitudinal clinical evaluation of post systems: a literature review. Braz Dent J 2012;23:135-140.

3. Ferrari M, Vichi A, Fadda GM, Cagidiaco MC, Tay FR, Breschi L, et al.. A randomized controlled trial of endodontically treated and restored premolars. J Dent Res 2012;91:72S-78S.

4. Santos AF, Meira JB, Tanaka CB, Xavier TA, Ballester RY, Lima RG, et al.. Can fiber posts increase root stresses and reduce fracture? J Dent Res 2010;89:587-591.

5. Bouillaguet S, Troesch S, Wataha JC, Krejci I, Meyer JM, Pashley DH. Microtensile bond strength between adhesive cements and root canal dentin. Dent Mater 2003;19:199-205.

6. de Sousa Menezes M, Queiroz EC, Soares PV, Faria-e-Silva AL, Soares CJ, Martins LR. Fiber post etching with hydrogen peroxide: effect of concentration and application time. J Endod 2011;37:398-402.

7. Menezes MS, Queiroz EC, Campos RE, Martins LR, Soares CJ. Influence of endodontic sealer cement on fibreglass post bond strength to root dentine. Int Endod J 2008;41:476-484.

8. Boone KJ, Murchison DF, Schindler WG, Walker WA 3rd. Post retention: the effect of sequence of post-space preparation, cementation time, and different sealers. J Endod 2001;27:768-771.

9. Vano M, Cury AH, Goracci C, Chieffi N, Gabriele M, Tay FR, et al.. The effect of immediate versus delayed cementation on the retention of different types of fiber post in canals obturated using a eugenol sealer. J Endod 2006;32:882-885.

10. Davis ST, O'Connell BC. The effect of two root canal sealers on the retentive strength of glass fibre endodontic posts. J Oral Rehabil
2007:34:468-473.

11. Mazzoni A, Marchesi G, Cadenaro M, Mazzotti G, Di Lenarda R, Ferrari $M$, et al.. Push-out stress for fibre posts luted using different adhesive strategies. Eur J Oral Sci 2009;117:447-453.

12. Hikita K, Van Meerbeek B, De Munck J, Ikeda T, Van Landuyt K, Maida T, et al.. Bonding effectiveness of adhesive luting agents to enamel and dentin. Dent Mater 2007;23:71-80.

13. Toman M, Toksavul S, Sarikanat M, Firidinoglu K, Akin A. The evaluation of displacement resistance of glass FRC posts to root dentine using a thin slice push-out test. Int Endod J 2009;42:802-810.

14. Faria e Silva AL, Casselli DS, Ambrosano GM, Martins LR. Effect of the adhesive application mode and fiber post translucency on the push-out bond strength to dentin. J Endod 2007;33:1078-1081.

15. Soares CJ, Santana FR, Castro CG, Santos-Filho PC, Soares PV, Qian $F_{1}$ et al.. Finite element analysis and bond strength of a glass post to intraradicular dentin: comparison between microtensile and push-out tests. Dent Mater 2008;24:1405-1411.

16. Cekic-Nagas I, Ergun G, Nagas E, Tezvergil A, Vallittu PK, Lassila LV. Comparison between regional micropush-out and microtensile bond strength of resin composite to dentin. Acta Odontol Scand 2008;66:7381.

17. Goracci C, Tavares AU, Fabianelli A, Monticelli F, Raffaelli O, Cardoso $\mathrm{PC}$, et al.. The adhesion between fiber posts and root canal walls: comparison between microtensile and push-out bond strength measurements. Eur J Oral Sci 2004;112:353-361.

18. Hagge MS, Wong RD, Lindemuth JS. Effect of three root canal sealers on the retentive strength of endodontic posts luted with a resin cement. Int Endod J 2002;35:372-378.

19. Correa Pesce AL, Gonzalez Lopez S, Gonzalez Rodriguez MP. Effect of post space preparation on apical seal: influence of time interval and sealer. Med Oral Patol Oral Cir Bucal 2007;12:E464-E468.

20. Soares CJ, Pereira JC, Valdivia AD, Novais VR, Meneses MS. Influence of resin cement and post configuration on bond strength to root dentine. Int Endod J 2012;45:136-145.

21. Onay EO, Alikaya C, Seker E. Evaluation of antifungal efficacy of erbium, chromium: yttrium-scandium-gallium-garnet laser against Candida albicans. Photomed Laser Surg 2010;28:S73-S78.

22. Behr M, Rosentritt M, Wimmer J, Lang R, Kolbeck $C$, Burgers $R$, et al.. Self-adhesive resin cement versus zinc phosphate luting material: a prospective clinical trial begun 2003. Dent Mater 2009;25:601-604.

23. Shemesh $\mathrm{H}$, Wu MK, Wesselink PR. Leakage along apical root fillings with and without smear layer using two different leakage models: a two-month longitudinal ex vivo study. Int Endod J 2006;39:968-976.

24. Paque $F$, Luder HU, Sener B, Zehnder M. Tubular sclerosis rather than the smear layer impedes dye penetration into the dentine of endodontically instrumented root canals. Int Endod J 2006;39:18-25.

25. Madruga FC, Ogliari FA, Ramos TS, Bueno M, Moraes RR. Calcium hydroxide, $\mathrm{pH}$-neutralization and formulation of model self-adhesive resin cements. Dent Mater 2013;29:413-418. 